\title{
Bone Transport of Tibia
}

\author{
Professor Dr. Omer Ali Rafiq Barawi,
}

M.B.CH.B.F.I.C.M.S (Orthopaedics), M.D.O.A. the Netherlands,

\section{Zmnako J. Amen,}

MSc in Biophysics RuG in Groningen, College of Medicine, University of Sulaimani, Kurdistan Regional Government of Iraq

Doi: 10.19044/esj.2018.v14n15p12 URL:http://dx.doi.org/10.19044/esj.2018.v14n15p12

\begin{abstract}
This is a comparative study to evaluate the outcome of forty patients with bone loss in tibia using conventional external fixation device for group A while for group B using Ilizarov external fixator device each group consists of 20 patients, based on principles of distractive osteogenesis. Patients and methods: Forty patients with bone loss of 4 to 14 centimeters in tibia between April 2011 and April 2016 were treated, ages (15-65 years); female to male ratio was $6: 34$. The cause of defects in tibia was fracture due to road traffic accident ( 20 cases), bullet injury to leg ( 8 cases), gap nonunion ( 8 cases) and infected non unions ( 4 cases). They were divided into two groups each consists of 20 patients, conventional external fixator used for group A while for group B Ilizarov external fixator device was used with performing transverse corticotomy proximal or distal to the gap for both groups. Results: Evaluation of results was done according to Association for Study and Application of Methods of Ilizarov (A.S.A.M.I.) scoring system and it revealed that both functional and bony results were better in group B than group A. Conclusions: Fixation of the bone by Ilizarov frame gives more rapid union of the bone, less chance of pin tract infection and cosmetically more preferable because of smaller scar tissue of entry of $\mathrm{K}$ wires than Schanz pins. Prevention and treatment of equinus deformity and clawing of the toes can be done by extending the Ilizarov frame to correct them. In cases of severe soft tissue loss it is better to apply conventional external fixator as a provisional fixator till the soft tissue loss and swelling will be diminished.
\end{abstract}

Keywords: Bone transport of tibia, Bone defect of tibia, Ilizarov method for reconstruction of tibia 


\section{Introduction}

Distraction osteogenesis is used not only for limb lengthening but also as a means of filling segmental defect in bone (Louis et al.,2010). Bone transport is a useful operation described by Ilizarov. With the advent of bone transport, the surgeon can boldly resect the entire avascular bone \& create a large defect. The procedure consists of corticotomy at one end of the long bone segment of the bone. The intercalary segment is transported; the gap is closed by two methods: gradual method and acute docking method (Kulkarni and Sohail, 2008). Acute shortening of more than $4 \mathrm{~cm}$ can cause the development of tortuous vasculature \& actually produce a low flow state with detrimental consequence. Open soft-tissue wounds when acutely compressed can become notably bunched and disvascular, with the development of significant edema $\&$ the possibility of additional tissue necrosis and infection (Tracy et al.,2007). Several techniques have been used to fill these defects including autologous cancellous bone graft, allograft, ipsilateral vascularized fibular transport (fibula protibia), bone transport and free vascularized fibular graft( Ahmed, 2006). In the new modification of internal bone transport technique the bone is axially transported also by internally placed transport pulley system (Bilal et al., 2008).

Microvacular techniques to transfer the fibula with its blood supply and sometimes with skin and muscles proved to be useful in overcoming large skeletal defects, but are highly demanding and having some drawbacks (Song et al., 2003). The advantage of ipsilateral vascularized fibular transport is that the fibular segment retains its vascularity without the need for microvascular dissection or anastomosis (Atkins et al., 1999). Ilizarov experimentally showed that when gradual distraction tension stress applied to the corticotomy site, the vascularity of the entire limb is increased, which in turn enhances the ability of the bone ends to unite (Mehtab et al.,2008). Because of difficulty in managing posttraumatic segmental bone defects and the resultant outcome, amputation historically was the preferred treatment (De Coster et al.,2004) . For hypertrophic non-unions with minimal infection and no sequestrated bone; Catagni recommended compression to increase formation of repair callus and vascularity. He reported that with this technique infection was spontaneously eliminated. Monofocal compression also used for infected hypertrophic non-unions with deformity. For atrophic non-unions with diffuse infection or sequestrated bone, open resection of the infected segment is performed, and bifocal compression is used (Terry and James, 2008). Ilizarov ring fixator is excellent treatment modality for tibial non-union with a defect, regarding bone union, deformity correction, infection eradication, limb length achievement and limb function but this needs prolonged learning curve for fresh orthopedic surgeons (Frmanullah et al.,2007). 
Cylindrical titanium mesh cage packed with a composite of cancellous allograft and demineralized bone matrix and stabilized with statically locked intramedullary nail is another method of treating bone loss (Bullens P., 2011). French technique of bone grafting within induced membrane, otherwise known as the Masqulet technique offers a variable alternative with minimal complications (Colin et al.,2010).

Table 1: Association for the Study of Applications of Methods of Ilizarov (A.S.A.M.I.) scoring system (Mohammad et al., 2010; Shahid et al.,2008).

\begin{tabular}{|c|l|}
\hline \multicolumn{2}{|c|}{ Bone Results } \\
\hline Excellent & Union, no infection, deformity $<7^{\circ}$ limb length discrepancy $<2.5 \mathrm{~cm}$ \\
\hline Good & $\begin{array}{l}\text { Union+ any two of the followings } \\
\text { No infection ,deformity }<7^{\circ} \text { limb length discrepancy }<2.5 \mathrm{~cm}\end{array}$ \\
\hline Fair & $\begin{array}{l}\text { Union }+ \text { only one of the following. } \\
\text { No infection, deformity }<7^{\circ} \text { limb length discrepancy }<2.5 \mathrm{~cm}\end{array}$ \\
\hline Poor & $\begin{array}{l}\text { Non-union / refracture } / \text { union }+ \text { infection }+ \text { deformity }<7^{\circ}+\text { limb } \\
\text { length discrepancy }>2.5 \mathrm{~cm}\end{array}$ \\
\hline Functional Results \\
\hline Excellent & $\begin{array}{l}\text { Active, no limp, minimum stiffness (loss of }<15^{\circ} \text { knee extension } /< \\
15^{\circ} \text { dorsiflexion of ankle), no reflex sympathetic dystrophy, } \\
\text { insignificant pain }\end{array}$ \\
\hline Good & $\begin{array}{l}\text { Active with one or two of the followings; } \\
\text { Limp, stiffness, R.S.D, insignificant pain }\end{array}$ \\
\hline Fair & $\begin{array}{l}\text { Active with three or all of the followings; } \\
\text { Limp, stiffness, R.S.D, significant pain }\end{array}$ \\
\hline Poor & $\begin{array}{l}\text { Inactive (unemployment or inability to return to daily activities because } \\
\text { of injury) }\end{array}$ \\
\hline Failure & Amputation \\
\hline
\end{tabular}

\section{Patients \& Methods}

Between April 2011 and April 2016, 40 patients (6 females 34 males) with bone loss ranging from 4.0-14.0 cm in tibia treated in Sulaimani and causality teaching hospitals. Their age ranged from 15-65 years old. Site of defects in 30 patients are lower $1 / 3$, in 6 patients the sites of bone loss were in the upper $1 / 3$ while in the remaining 4 patients the site of bone loss was in the mid $1 / 3$ of tibia. After taking informed written consent from patients, the conventional monolateral external fixator frame were preassembled, for all of the cases of group A. In the preoperative radiograph of the leg, two radiopaque markers were used to localize the most proximal and most distal parts of the tibia which is helpful in application of external fixator and minimizing the use of fluoroscope intraoperatively.

The site of the defect was exposed \& all unhealthy bone and any dead tissue was removed, the fibula is fixed internally by K-wire. After frame application the alignment is checked by fluoroscope and a separate incision was used to perform corticotomy proximal to the defect if the defect in the distal $1 / 3$, distal to the defect if the defect in the proximal $1 / 3$ of the tibia and 
bifocal corticotomy when the defect in the middle of the tibia $\&$ it is massive gap (when the gap is $\geq 11 \mathrm{~cm}$ ). Corticotomy done by multiple drill holes method through $1 \mathrm{~cm}$ longitudinal skin incision after making the frame rod loose multiple holes done in the anterior, medial and lateral cortices then rotating the sharp osteotome at right angle the corticotomy will be completed and the clunk of corticotomy will be heard the frame is then retightened.

Distraction started manually 3 days post operatively although this is early according to the majority of the papers. The intercalary segment transported toward the gap $1 \mathrm{~mm}$ daily, in four divided doses i.e. $0.25 \mathrm{~mm}$ each 6 hours if it is unifocal corticotomy but if it is bifocal it will be $2 \mathrm{~mm}$ daily i.e. $1 \mathrm{~mm}$ for each corticotomy site. While for 20 patients of group B the Ilizarov frame is preassembled preoperatively and corticotomy done similar to group A patients.

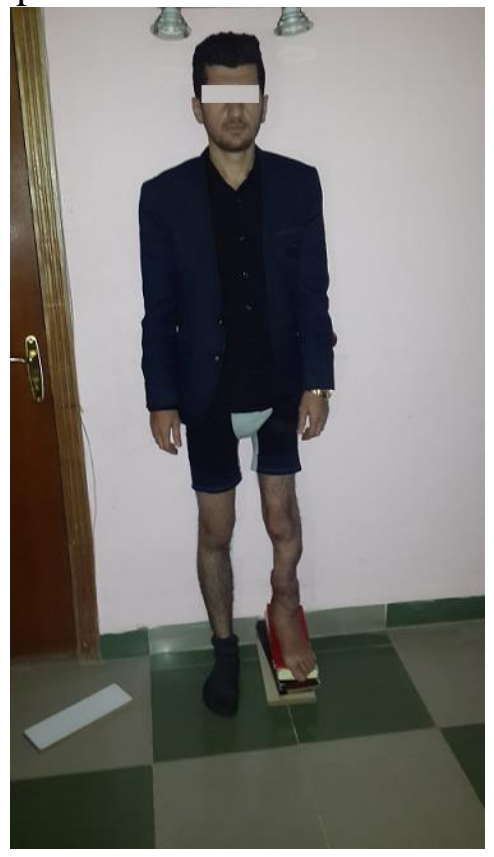

Fig. 1-a: Shows wooden block under the shorter site ( $11.0 \mathrm{~cm}$ clinically $3.0 \mathrm{~cm}$ radiologically) and scar tissues of previous operations.

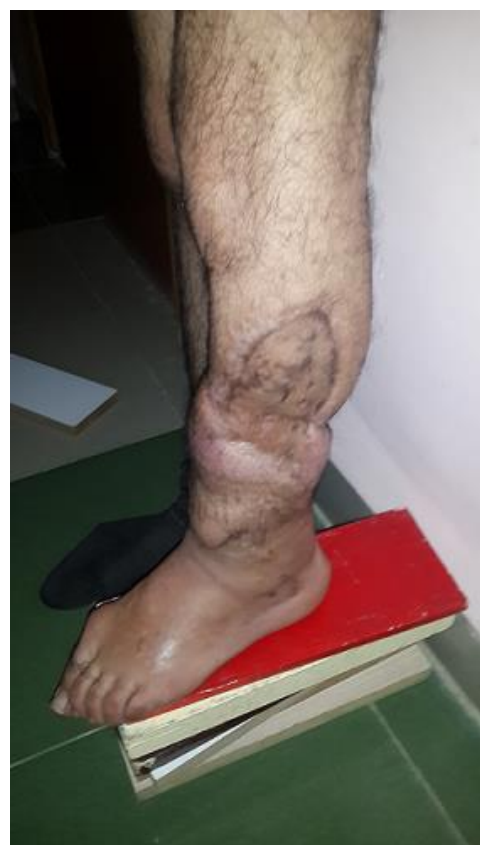

Fig. 1-b: The same patient irregular scar tissues of previous operations. 


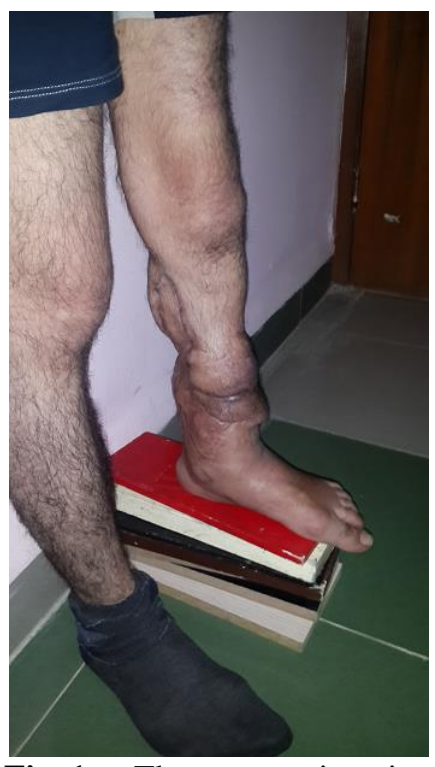

Fig. 1-c: The same patient, irregular scar tissues of previous operations.

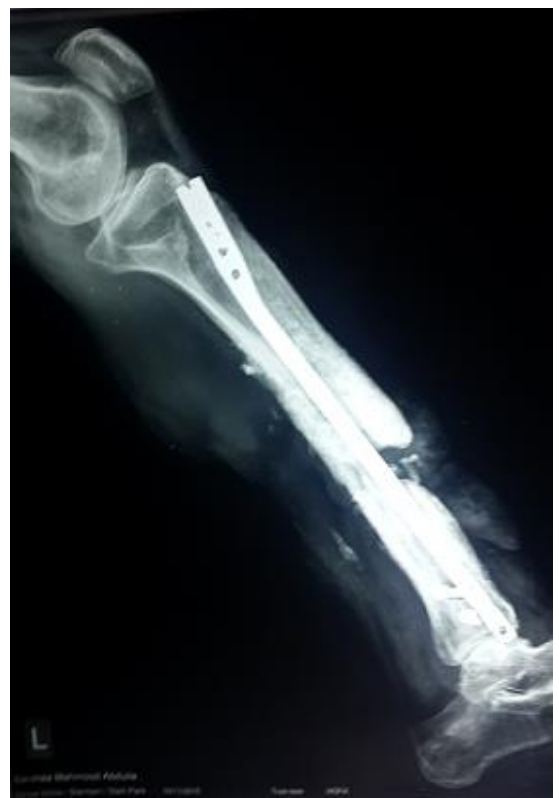

Fig. 1-e: Plain radiograph of the same patient lateral view showing implant failure downward migration of the nail and nonunion of the tibia (3.0 $\mathrm{cm}$ is the gap).

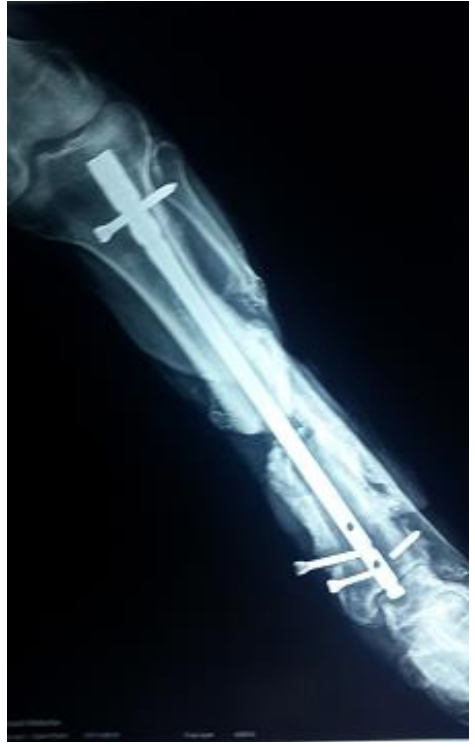

Fig. 1-d: Plain radiograph of the same patient A.P.

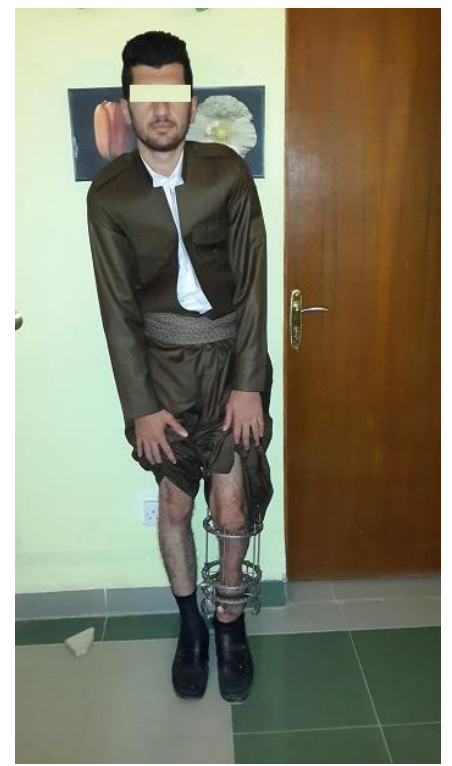

Fig. 1-f: The same patient with Ilizarov frame in his left leg. 


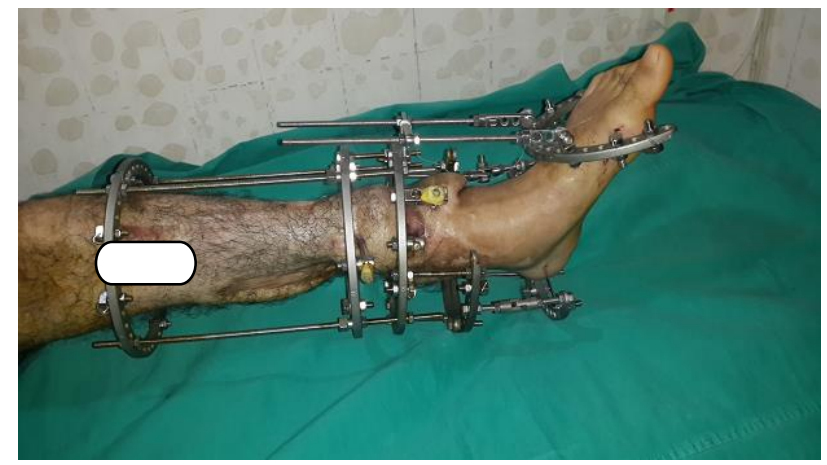

Fig. 1-g: The frame is extended to involve ankle and foot for the correction of equinus deformity.

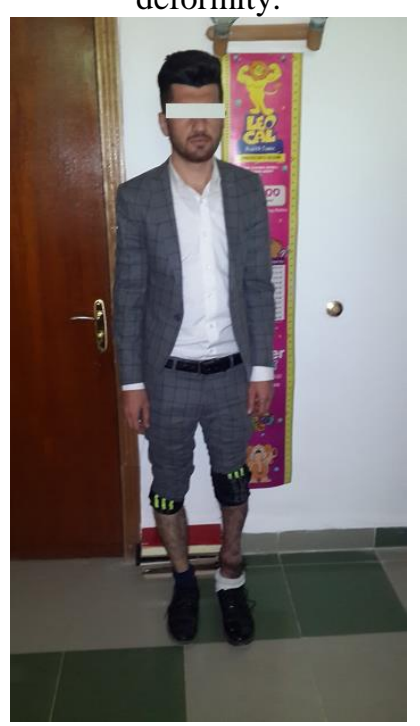

Fig. 1-h: The same patient after removal of the frame well equalized limbs he can stand without support.

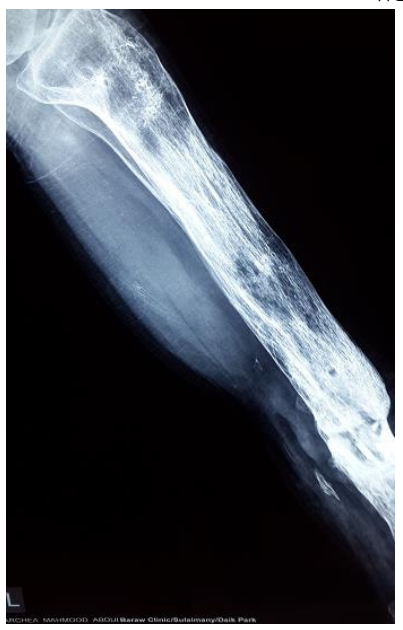

Fig. 1-i: Plain Radiograph of the left leg lateral view.

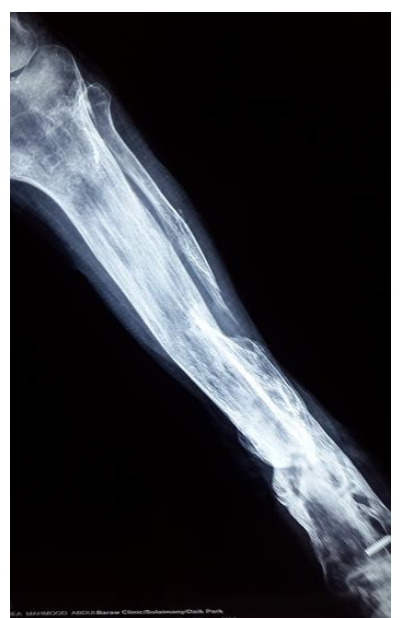

Fig. 1-j: Plain Radiograph of the left leg A.P. view after removal of the external fixator. 


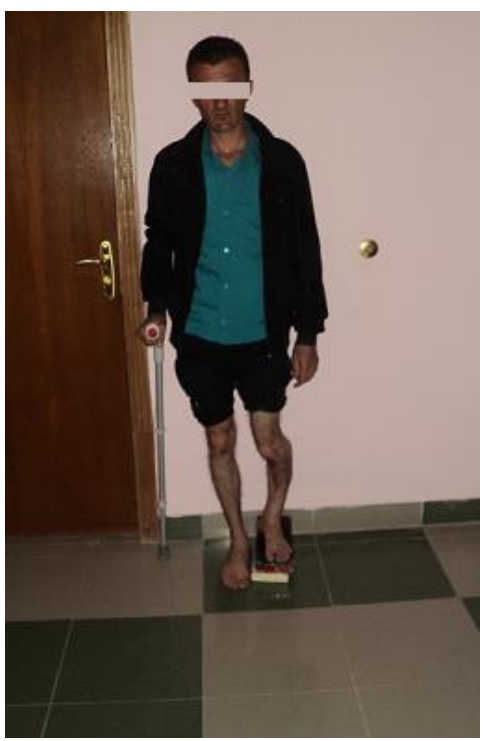

Fig. 2-a:Twenty eight years old man with chronic osteomyelitis of left tibia for the last 20 years as a complication of fracture tibia and tight bandaging causing $11 \mathrm{~cm}$ gap.

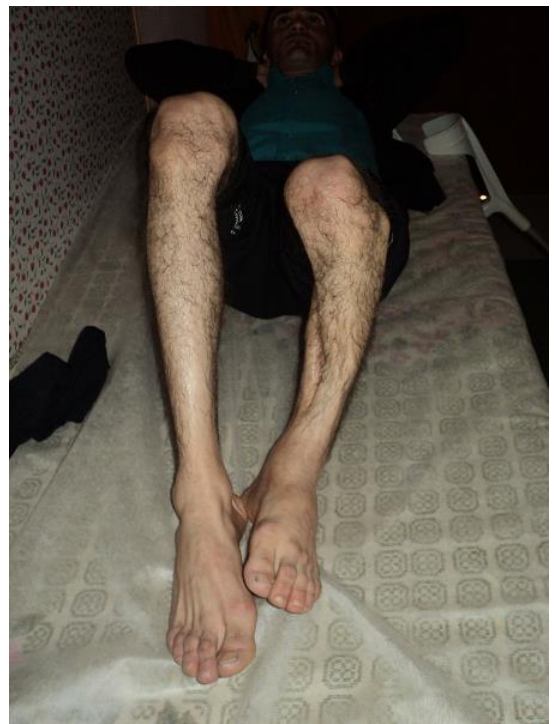

Fig. 2-c: The same patient with protruded head fibula and scar tissue on the shin the site of repetitive sequestrectomies.

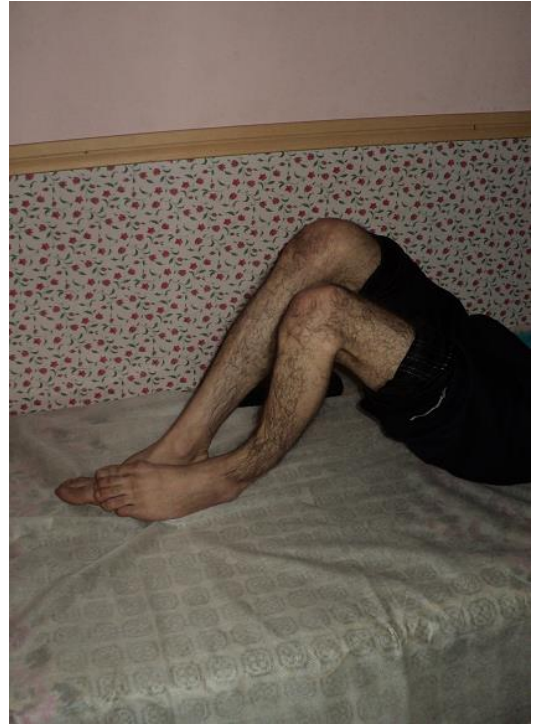

Fig. 2-b: The same patient in supine position shortening and bowing of left leg.

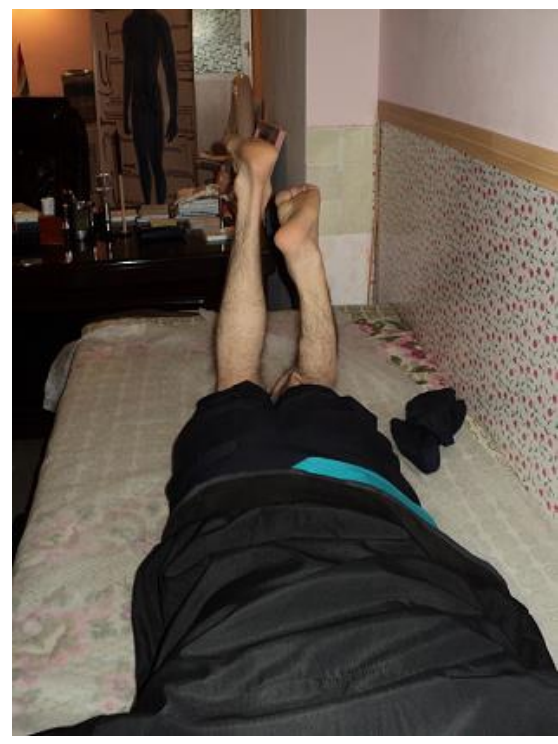

Fig. 2-d: The same patient in prone position. 


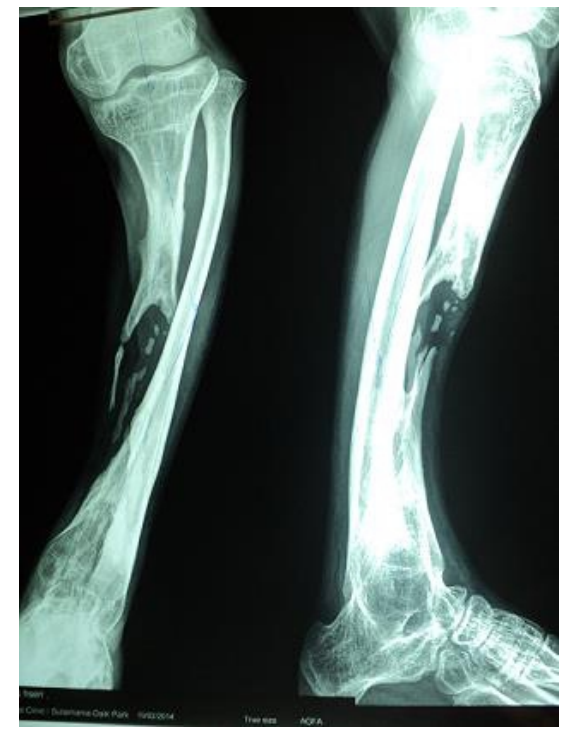

Fig. 2-e: Plain radiograph, A.P. \& Lat. views, multiple sequestrae gap in the tibia \& ankylosed ankle.

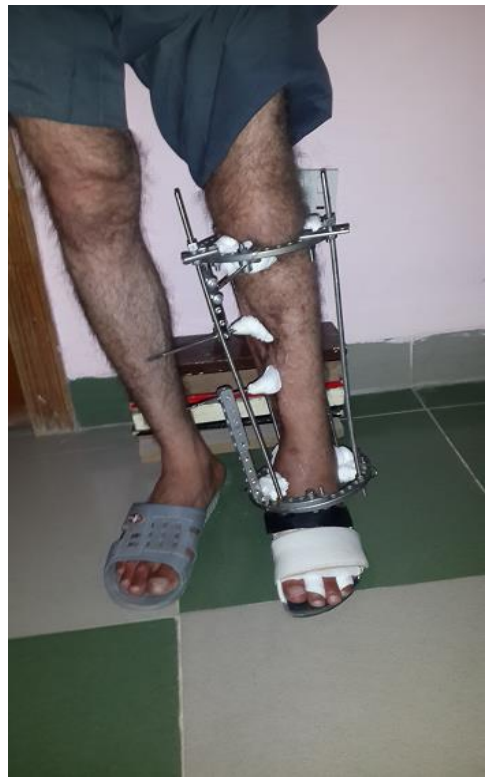

Fig. 2-g: The same patient after removal of the middle block of the Ilizarov frame no more bowing of the leg and well equalized limb.

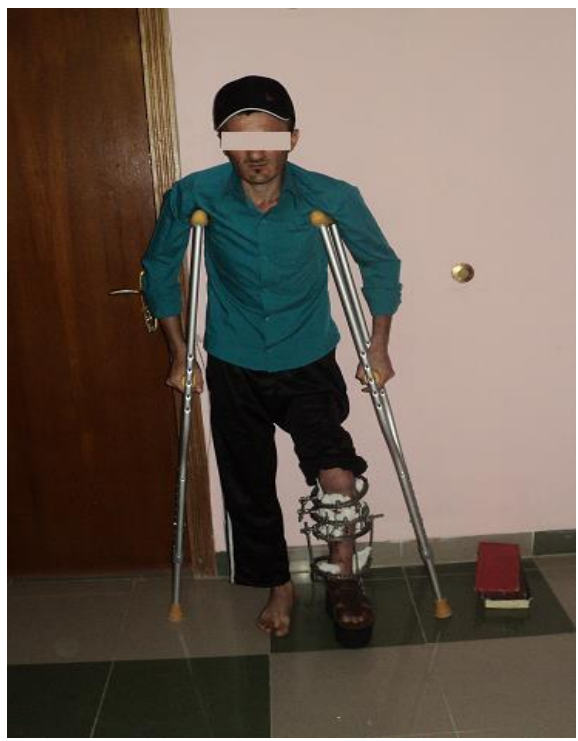

Fig. 2-f: The same patient with Ilizarov frame, 4 in 1 . The middle block for compression of Fibula-Pro-Tibia (Ipsilateral Vascularized Fibular Transport) while proximal and distal blocks for correction of bowing and elongation.

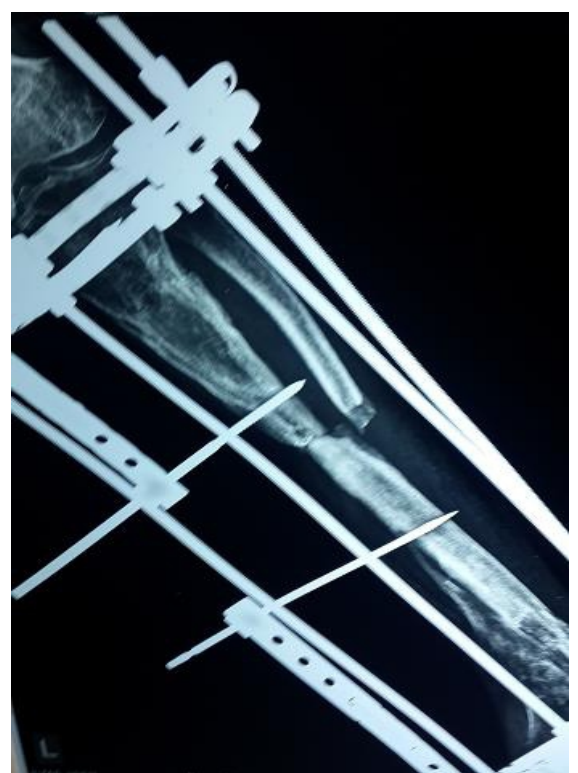

Fig. 2-h: A Plain radiograph A.P view well corticalised distraction sites hypertrophied distal fragment of fibula 


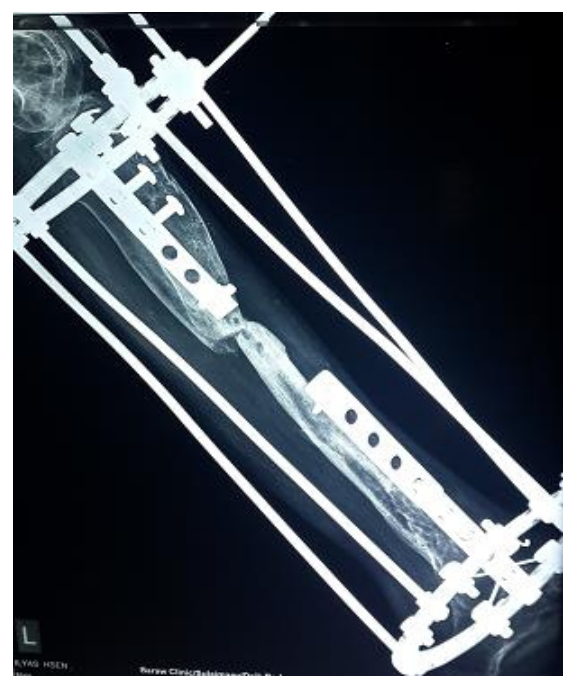

Fig. 2-i: Plain radiograph Lat. view well corticalised distraction sites hypertrophied distal fragment of fibula.

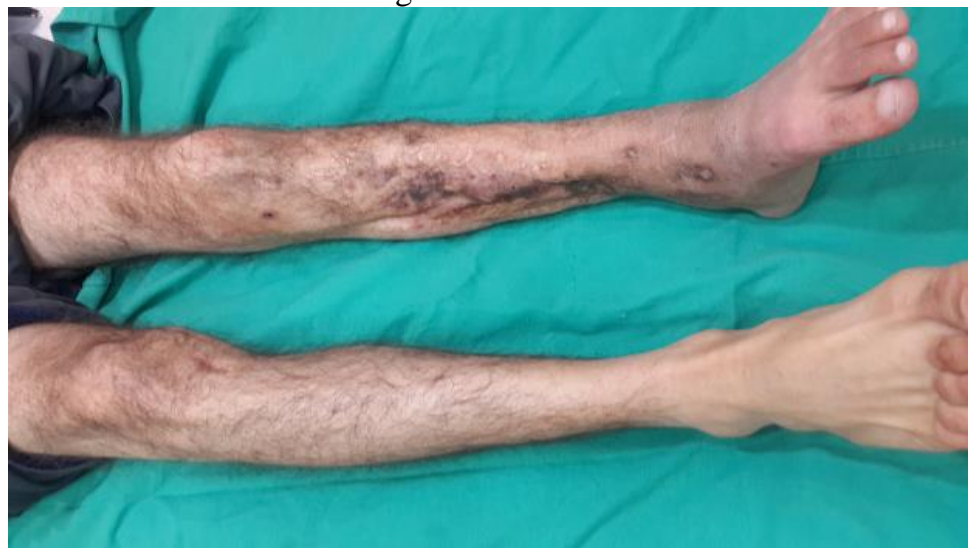

Fig. 2-j: The same patient after removal of the Ilizarov frame. 


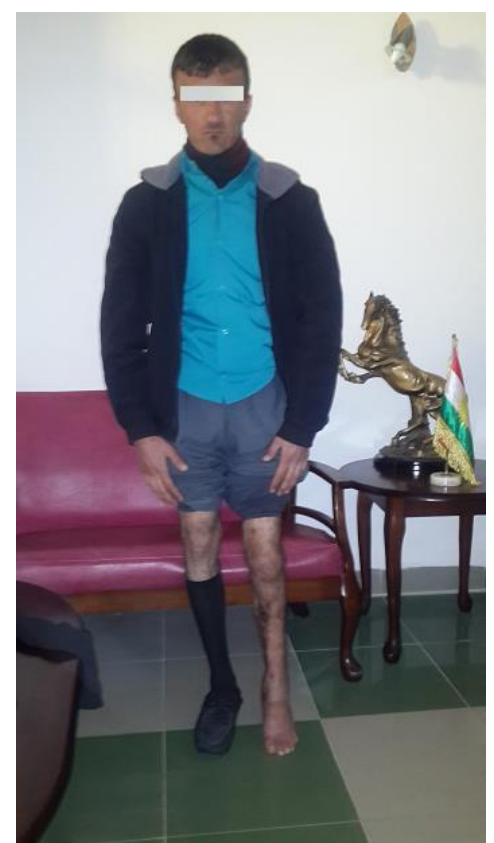

Fig. 2-k: The same patient well equalized limbs standing without support no more sinuses.

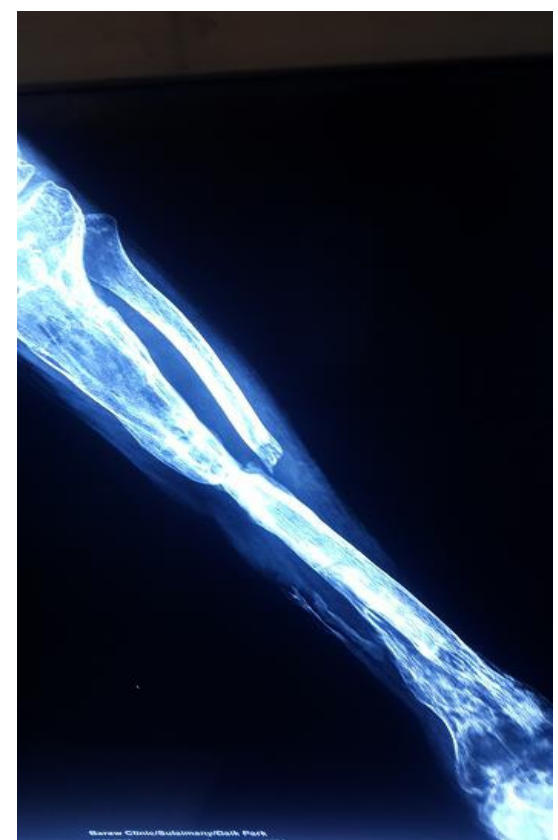

Fig. 2-L: A.P. view showing union of distal fragment of fibula with proximal fragment of tibia well corticalised distraction sites.

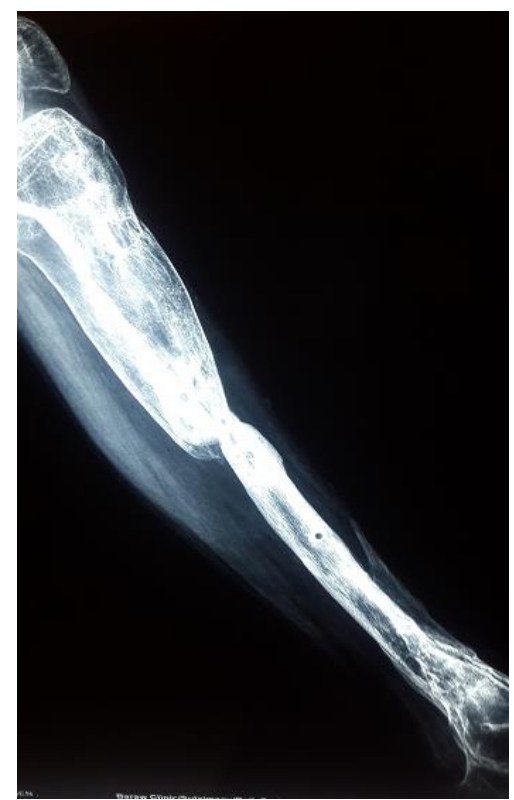

Fig. 2-m: Lateral view of the same patient. 


\section{Results}

In the current study out of 40 patients, 6 patients $(15 \%)$ were female and 34 patients $85 \%$ male. Their age ranged between 15-65 years (average 31.75). The causes of defects was fracture tibia by Road Traffic Accident in 20 cases (\%50), bullet injury in 8 cases (\%20), gap non-union in 8 cases $(\% 20)$ and infected non-union in 4 cases (\%10). The average length of bone loss was $7.9 \mathrm{~cm}$ (ranging from $4-14 \mathrm{~cm}$ ).

The results were divided into bony and functional results according to (A.S.A.M.I.) scoring system table 2, in group A patients bony result was excellent in 12 patients $(60 \%)$, good in 2 patients $(10 \%)$, fair in 4 patients $(20 \%)$ and poor in 2 patients ( $10 \%$ ) while functional result was excellent in 11 patients $(55 \%)$, good in 3 patients $(15 \%)$, fair in $4(20 \%)$ and poor in 2 patients ( $10 \%$ ), no failure as none of them ended by amputation.

Regarding group B patients, the bony results was excellent in 14 patients $(70 \%)$, good in 3 patients $(15 \%)$, fair in 2 patients $(10 \%)$, poor 1 patient $(5 \%)$, while functional result was excellent in 13 patients $(65 \%)$, good in 4 patients $(20 \%)$, fair 2 patients $(10 \%)$ and poor 1 patient $(5 \%)$, no failure as none of them ended by amputation. Due to the less of the data couples we couldn't do statistic analysis especially probability value (p-value); however both groups have good correlation coefficient $(r=0.97)$.

Table 2: Bony and functional results of both groups according to (A.S.A.M.I.) scoring systems.

\begin{tabular}{|c|c|c|c|c|}
\hline \multirow{2}{*}{ Bony Results } & \multicolumn{2}{|c|}{$\begin{array}{c}\text { Group A using conventional } \\
\text { External fixation }\end{array}$} & \multicolumn{2}{c|}{ Group B suing Ilizarov frame } \\
\cline { 2 - 5 } & No. Patients & Percentage & No. Patients & Percentage \\
\hline Poor & 2 & $10 \%$ & 1 & $5 \%$ \\
\hline Fair & 4 & $20 \%$ & 2 & $10 \%$ \\
\hline Good & 2 & $10 \%$ & 3 & $15 \%$ \\
\hline Excellent & 12 & $60 \%$ & 14 & $70 \%$ \\
\hline Total & 20 & $100 \%$ & 20 & $100 \%$ \\
\hline \multirow{2}{*}{$\begin{array}{c}\text { Functional } \\
\text { Results }\end{array}$} & \multicolumn{2}{|c|}{ Group A using conventional } & \multicolumn{2}{c|}{ Group B suing Ilizarov frame } \\
\cline { 2 - 5 } & No. Patients & Percentage & No. Patients & Percentage \\
\hline Poor & 2 & $10 \%$ & 1 & $5 \%$ \\
\hline Fair & 4 & $20 \%$ & 2 & $10 \%$ \\
\hline Good & 3 & $15 \%$ & 4 & $20 \%$ \\
\hline Excellent & 11 & $55 \%$ & 13 & $65 \%$ \\
\hline Total & 20 & $100 \%$ & 20 & $100 \%$ \\
\hline
\end{tabular}

Table 3: showing external fixation time, external fixation index and average bone defect of both group A and group B patients.

\begin{tabular}{|c|c|c|c|}
\hline & $\begin{array}{c}\text { External fixation } \\
\text { Time (Months) }\end{array}$ & $\begin{array}{c}\text { External fixation } \\
\text { Index (Days/cm) }\end{array}$ & $\begin{array}{c}\text { Average bone } \\
\text { defect }(\mathrm{cm})\end{array}$ \\
\hline Group A & 9.2 & 32.8 & 8.3 \\
\hline Group B & 7.65 & 29.6 & 7.3 \\
\hline
\end{tabular}




\section{Complications}

1. Residual limb length discrepancy was observed in 4 patients with maximum $10 \mathrm{~mm}$; which 3 patients were in group A (15\%) and 1 patient $(5 \%)$ in group $\mathrm{B}$.

2. In group A five patients had pin tract infection three of them were grade 2 in which treated by proper hygiene and antibiotic according a culture and sensitivity while other two patients had grade 3 pin tract infection and they treated by change of the pin in the theater while in group B three of the patients had pin tract infection with grade 2 in which they treated by good hygiene and antibiotic according to culture and sensitivity (Checketts et al.,2008) .

3. Equinus deformity and clawing of the toes were observed in 4 patients from group A $(20 \%)$.

4. The reflex sympathetic dystrophy occurs with 4 patients $(10 \%)$ in both groups.

5. In group A there were 2 cases (10\%) of knee stiffness and 4 cases $(20 \%)$ of ankle stiffness while,in group B there were 2 cases $(10 \%)$ of ankle and knee stiffness respectively.

6. Only 2 patients (10\%) from group A and 1 patient (5\%) from group $\mathrm{B}$ incompetence to do their jobs.

7. Re fracturing only 2 patients (10\%) from group A.

\section{Discussion}

Conventional external fixator was used in the study for group A because it was more available and cheap and easy assembly. Open reduction and internal fixation of fibula done by K-wire (if the fibula was broken) to give you more stability and to guide the transported tibial segment toward the gap and minimize chance of malalignment which is important from the reconstruction aspect of the leg. So by using monolateral external fixator to anteromedial aspect of the shin which is a safe corridor and it is less cumbersome to the patient during walking. In 2 cases from group A and 1 case from group B patients functional results were poor so they couldn't return back to their job the cause behind that was the obligatory muscle shortening of the muscle length, suggesting that adaptive muscle changes had occurred at the level of transported muscles which affects both routine and maximal effort capabilities (Konstantinos et al., 2005).

Patient selection and education regarding the duration of treatment, emotional, financial and social support are absolutely essential (Thayur et al., 2008). That is why 6 of the patients disagree to participate in the current study, so only 40 patients remained for participation and follow up. Regarding the patient in Fig. 2, we opted fibula pro -tibia, then fixation by Ilizarov frame and bifocal bone transport, but without any soft tissue debridement and 
sequestrectomies, the sequestrae were came out through the sinuses spontaneously post operatively this is similar to a case report by Macro Turati compression of tibial septic hypertrophic nonunion using hexapod external fixator without debridement (Marco B et al., 2017).

Multiplaner Ilizarov external fixator and uniplanner monofixator has been used for bone transport but none has been proven to be free of complications. A study done by Sangkaew C showed that average bone transport of $(5.6 \mathrm{~cm})$ and average fixator time was 8 months in 21 patients (Mohammad et al., 2010), he used conventional external fixator in his study while in our study for group A of the patients average bone transport of 8.3 $\mathrm{cm}$ and average fixator time is 9.2 months which means shorter average fixator time. Using Ilizarov fixator Dendrinoset et al., achieved healing in 9.6 months with $6 \mathrm{~cm}$ bone transport in 28 patients (Mohammed et al., 2010). While in group B of the patients of the current study healing achieved in 7.65 months with average bone transport $7.9 \mathrm{~cm}$.

Distraction started manually 3 days post operatively although this is early according to the majority of the papers, this may be due to the fact that the total number of the patients were not large and the majority of them were young and the cause of gaps were trauma causing hypervascularity of the entire limb.

\section{Conclusion}

Tibial bone defect can be treated successfully by bone transport using Ilizarov frames. The Ilizarov frames give more rapid union and less chance of pin tract infection and cosmetically more preferable because of smaller scar tissue of entry of $\mathrm{K}$ wires than Schanz pins in conventional external fixator. Prevention and treatment of equinus deformities and clawing of the toes can be done by extending the Ilizarov frame to include ankle, foot and toes.

\section{Recommendations}

In cases of severe soft tissue loss it is better to apply conventional external fixator as provisional fixator till the soft tissue loss and swelling will be diminished. In every case of compound comminuted fractured tibia with or without bone loss; the external fixator should be applied in a manner not to prevent bone transport whenever need it.

\section{References:}

1. Ahmed M. Abdel-Aal (2006). Ilizarov Bone Transport for Massive Tibial Bone Defects Orthopaedics J, 29,70-74.

2. Atkins R. M, P. Madhavan, J. Sudhkar, D. Whitwell.(1999). Ipsilateral vascularised fibular transport for massive defects of the tibia. Bone Joint Surg [Br], 81-B,1035-40. 
3. Bilal Demir, Kahraman Ozturk, Ramadan Oke, Sarper Gursu, Kerem B. Aydin, Vedat Sahi(2008). A modified technique of internal bone transport. Acta Orthop. Belg, 74,216-221.

4. Bullens P. Reconstruction of segmental long bone defects (2011). Clinical orth Relat Res, 467 (3), 24.

5. Checketts, R.G. MacEachem A.G., Otterbum M. (2008). Pin Tract Infection and the Principles of Pin Site Care.Orthofix External fixation in Truma and Orthopaedics, 97-103.

6. Colin Yi-Loong Woon, MBBS, MRCSE Ed, MMed (Surg), MMed(ortho), Keen-Wai Chong, MBBS, MRCS(Edin), MMed (ortho), FRCS (Edin) (ortho) and Merug-Koon Wong, MBBS, FRCS(Glasg), FAMS(2010). Induced membrane- a staged technique of bone-grafting for segmental bone loss, a report of two cases and a literature review. J. Bone Joint Surg. Am., 92(1), 196-201.

7. De Coster TA, Gehlert R J, Mikola EA, Pierla-Cruz MA.(2004.) Management of posttraumatic segmental bone defects. J Am Acad Orthop Surg, Jan-Feb,12 (1),28-38.

8. Frmanullah,Muhammad Shoaib Khan and Syed Muhammad Awias (2007). Evaluation of management of tibial Non-union defect with Ilizarov fixator.J Ayub Med Coll Abbottabad, 19 ,3.

9. Konstantinos A. Giannikas, Constantinos N. Maganaris, Michael T. Karski, Peter Twigg, Richard A. Wikes and John G. Buckley(2005). Functional Outcome Following Bone Transport Reconstruction of Distal Tibial Defects. Journal of Bone \& Joint Surgery Am., 87, 145152.

10. Kulkarni, G.S. \& Sohail, M.T.(2008). Aggressive treatment of chronic osteomyelitis. Orthopedics and Trauma ( $2^{\text {nd }}$ ed.), vol. 2, 199, 17821784, JAYPEE.

11. Louis Solomon, David Warwick, Selvadurai Nayagam (2010). Distraction Osteogenesis and limb reconstruction - Ilizarov method: Apley's system of orthopedics and fractures ( $9^{\text {th }}$ ed.) $12,320 . U K$ : Hodder Arnold and Hachette publisher.

12. Mehtab A. Pirwani, M. Aslam Siddiqui, Yunis H. Soomro (2008). Management of infected non-union tibia by itercalary bone transport. Pakistan Journal of Surgery, 1,29.

13. Marco BIGONI, Marco TURATI, David AFONSO, Yann GLARD (2017). Compression of tibial septic hypertrophic nonunion using Hexapod external fixator without debridement: a possible option in selected cases. Minerva Ortopedica e Traumatologica J,June, 68 (2), 126-9.

14. Mohammad Shabir, Mohammad Arif, Abdul Satar, Mohammad Inam (2010). Distraction osteogenesis in segmental bone defects in tibia by 
monoaxial external fixator. JPMI, 24 (2), 133-137.

15. Shahid Hussain, Mohammad Inam, Muhammad Arif, Mohammad Shabir, Israr Ahmad(2008). Limb Length Discrepancy in Lower Limb Management with unilateral external fixator. JPMI, 22 (4), 285-291.

16. Song HR, Kalen A, Park HB.(2003). Comparison of internal bone transport and vascularised fibular graft for tibial bone defects. J. Orthop. \&Trauma, 17,203-211.

17. Terry Canale and James H .Beaty (2008). Cambell's Operative Orthopaedics, Deformity, shortening, and segmental Bone Loss Ilizarov Method (1 $1^{\text {th }}$ ed.). Mosby Elsevier publisher, vol. 3, p.35423543.

18. Thayur R Madhusudhan, Balasundaram Ramesh, KS Manjunath, Harshad M Shad, Dabir C Sundaresh and N Krishnappa (2008). Outcomes of Ilizarov ring fixation in recalcitrant infected tibial nonunion - a prospective study. Journal of Trauma Management and Outcomes. doi:10,1186 j. paid 2008.1752-2897-2-6.

19. Tracy J. Watson and Djoldas Kuldjanov (2007). Limb Lengthening and Reconstruction Surgery.USA, S. Robert Rozbruch, Svetlana Ilizarov publisher, Iforma healthcare,14, p.187. 